Januari - Juni 2021: 90 - 106

\title{
PENGARUH PROFITABILITAS, LAVERAGE, UKURAN PERUSAHAAN, REPUTASI KANTOR AKUNTAN PUBLIK (KAP) DAN KOMITE AUDIT TERHADAP KETEPATAN WAKTU PENYAMPAIAN LAPORAN KEUANGAN PADA PERUSAHAAN INDUSTRI BARANG KONSUMSI YANG TERDAFTAR DI BURSA EFEK INDONESIA (BEI)
}

\author{
Devi Ayu Putri S \\ Universitas Medan Area \\ deviputrisrt@gmail.com
}

\begin{abstract}
This study aims to examine and analyze the effect of profitability, leverage, firm size, reputation of public accountingfirm and audit committeeon timeliness of financial statement submission. This research was conducted at manufacturing industry sector of consumer goods sector in 2012-2016 at Indonesia Stock Exchange. Methods of research data using nonparticipant observation method, by analyzing the annual report and audit financial statements obtained. Data analysis method is logistic regression analysis, with hypothesis testing done by multivariate test. The result of the research shows that profitability and audit committee have positive effect on the timeliness of financial statement submission, while leverage, company size, reputation of public accountant officehave no effect on the timeliness of financial reporting. With this research, it is expected to provide significant implications for the parties concerned in assessing and predicting the timeliness of financial statement submission. Keywords: Profitability, leverage, company size, auditor reputation,commite audit, timeliness of financial reporting
\end{abstract}

\begin{abstract}
Abstrak
Penelitian ini bertujuan untuk menguji dan menganalisis pengaruh profitabilitas, leverage, ukuran perusahaan, reputasi KAP dan komite audit terhadap ketepatan waktu penyampaian laporan keuangan. Penelitian ini dilakukan pada sektor industri manufaktur sektor barang konsumsi tahun 2012-2016 di Bursa Efek Indonesia. Metode data penelitian menggunakan metode observasi nonpartisipan, dengan menganalisis laporan tahunan dan audit laporan keuangan yang diperoleh. Metode analisis data adalah analisis regresi logistik, dengan pengujian hipotesis dilakukan dengan uji multivariat. Hasil penelitian menunjukkan bahwa profitabilitas dan komite audit berpengaruh positif terhadap ketepatan waktu penyampaian laporan keuangan, sedangkan leverage, ukuran perusahaan, reputasi kantor akuntan publik tidak berpengaruh terhadap ketepatan waktu pelaporan keuangan. Dengan adanya penelitian ini diharapkan dapat memberikan implikasi yang signifikan bagi pihak-pihak terkait dalam menilai dan memprediksi ketepatan waktu penyampaian laporan keuangan.

Kata kunci: Profitabilitas, leverage, ukuran perusahaan, reputasi auditor, audit komite, ketepatan waktu pelaporan keuangan
\end{abstract}




\section{Pendahuluan}

Salah satu sumber informasi penting dalam bisnis investasi di pasar modal adalah laporan keuangan yang disediakan setiap perusahaan yang Go Public. Laporan keuangan yang berkualitas dapat memberikan informasi yang bermanfaat bagi pihak internal maupun pihak eksternal seperti investor, kreditor, dan pemasok untuk mengambil keputusan.

Ketepatan waktu (timeliness) pelaporan keuangan merupakan karakteristik penting bagi laporan keuangan. Selain itu, laporan keuangan yang dilaporkan secara tepat waktu akan mengurangi resiko ketidaksesuaian penafsiran informasi yang disajikan. Ketepatan waktu penyajian laporan keuangan ke publik adalah sebagai sinyal dari perusahaan yang menunjukkan adanya informasi yang bermanfaat untuk memenuhi kebutuhan investor dalam pembuatan keputusan. Manfaat laporan keuangan akan berkurang jika laporan tersebut tidak tepat waktu (1AI 2002).

Tepat waktu(timeliness) didefinisi sebagai suatu pemanfaatan informasi oleh pengambil keputusan sebelum informasi tersebut kehilangan kapasitas atau kemampuan untuk mengambil keputusan. Ketepat waktuan (timeliness) adalah informasi yang ada siap untuk digunakan sebelum kehilangan makna oleh pemakai laporan keuangan serta kapasitasnya masih tersedia dalam pengambilan keputusan (IAI, 2012). Ketepatan waktu pelaporan keuangan merupakan salah satu faktor penting dalam menyajikan suatu informasi yang relevan. Karakteristik informasi yang relevan harus mempunyai nilai prediktif dan disajikan tepat waktu (Chariri dan Ghozali, 2001). Seiring dengan berjalannya waktu, manfaat dari informasi yang terkandung dalam laporan keuangan akan semakin berkurang jika tidak disampaikan kepada pengguna laporan keuangan tepat waktu. Semakin cepat disampaikan, informasi yang terkandung di dalamnya semakin bermanfaat, dan para pengguna laporan keuangan dapat mengambil keputusan yang lebih baik. Laporan keuangan sebagai sebuah informasi akan bermanfaat apabila informasi yang dikandungnya disediakan tepat waktu bagi pembuat keputusan sebelum informasi tersebut kehilangan kemampuannya dalam mempengaruhi pengambilan keputusan (Chariri dan Ghozali, 2001). Kebutuhan akan ketepatan waktu pelaporan keuangan secara jelas telah disebutkan dalam kerangka dasar penyusunan penyajian laporan keuangan bahwa ketepatan waktu merupakan 
92 AT-TA WASSUTH: Jurnal Ekonomi Islam, Volume VI No. 1

Januari - Juni 2021: 90 - 106

salah satu karakteristik kualitatif yang harus dipenuhi, agar laporan keuangan yang disajikan relevan untuk pembuatan keputusan. Profesi akuntansi pun mengakui akan kebutuhan terhadap ketepatan waktu penyampaian laporan keuangan. Hal ini ditunjukkan dalam pekerjaan akuntan yang selalu berusaha untuk tepat waktu dalam menyajikan laporan keuangan.

Jika terdapat penundaan yang tidak semestinya dalam pelaporan keuangan, maka informasi yang diberikan akan kehilangan relevansinya. Informasi yang relevanadalahinformasi yang predictable, mempunyaifeed back value sertatepatwaktu (Annisa, 2004). Hal ini mencerminkan betapa ketepat waktuan (timeliness), merupakan salah satu faktor penting dalam penyajian laporan keuangan kepada public sehingga perusahaan diharapkan untuk tidak menunda penyajian laporan keuangannya agar informasi tersebut tidak kehilangan kemampuannya dalam mempengaruhi pengambilan keputusan.

\section{Kajian Teori}

\section{Signaling Theory}

Signaling Theory mengemukakan tentang bagaimana seharusnya sebuah perusahaan memberikan sinyal kepada pengguna laporan keuangan. Sinyal ini berupa informasi mengenai apa yang sudah dilakukan oleh manajemen untuk merealisasikan keinginan pemilik. Sinyal dapat berupa promosi atau informasilain yang menyatakan bahwa perusahaan tersebut lebih baik daripada perusahaan lain. Teori sinyal menjelaskan bahwa pemberian sinyal dilakukan oleh manajeruntuk mengurangi asimetri informasi.Signaling theory menjelaskan mengapa perusahaan mempunyai doronganuntuk memberikan informasi laporan keuangan pada pihak eksternal, karena terdapat asimetri informasi (Asymmetri Information) antara perusahaan dan pihakluar. Perusahaan (agent) mengetahui lebih banyak mengenai perusahaan dan prospek yang akan datang daripada pihak luar (investor, kreditor). Kurangnya informasi pihak luar mengenai perusahaan menyebabkan mereka melindungi diri mereka dengan memberikan harga yang rendah untuk perusahaan. Perusahaan dapat meningkatkan nilai perusahaan, dengan mengurangi asimetri informasi.Salah satu cara untuk mengurangi informasi asimetri adalah dengan memberikan sinyal pada pihak luar, 
salah satunya berupa informasi keuangan yang dapat dipercaya dan akan mengurangi ketidakpastian mengenai prospek perusahaan yang akan datang (Wolk et al., 2000 dalam Jama'an, 2008 ).

Ketepatan Waktu

Ketepatan waktu menunjukkan rentang waktu antara penyajian informasi yang diinginkan dengan frekuensi pelaporan informasi. Informasi yang tepat waktu akan mempengaruhi kemampuan penggunanya dalam merespon setiap kejadian atau permasalahan. Apabil ainformasi itu tidak disampaikan dengan tepat waktu akan menyebabkan informasi tersebut kehilangan nilai di dalam mempengaruhi kualitas keputusan. Informasi yang tepatwaktu juga akan mendukung manajer dalam menghadapi ketidakpastian yang terjadi dalam lingkungan kerja mereka (Suharli dan Harahap, 2008). Informasi tidak dapat dikatakan relevan jika tidak tepat waktu, informasi harus tersedia untuk pengambilan keputusan sebelum informasi tersebut kehilangan kesempatan untuk mempengaruhi pengambilan keputusan (Chariri dan Ghozali, 2001). Informasi mengenai kondisi dan posisi perusahaan harus secara cepat dan tepat waktu sampai kepemakai laporan keuangan. Ketepatan waktu mengimplikasikan bahwa laporan keuangan seharusnya disajikan pada suatu interval waktu, untuk menjelaskan perubahan dalam perusahaan yang akan mempengaruhi pemakai informasi dalam membuat prediksi dan keputusan (Srimindarti, 2008).

Profitabilitas

Profitabilitas merupakan rasio yang bertujuan untuk mengetahui kemampuan perusahaan dalam menghasilkan laba selama periode tertentu dan juga memberikan gambaran tentang efektifitas manajemen dalam melaksanakan kegiatan operasinya. Efektifitas manajemen disini dilihat dari laba yang dihasilkan terhadap penjualan dan investasi perusahaan. Profitabilitas adalah kemampuan perusahaan untuk menghasilkan laba dalam periode tertentu (Munawir, 1995). Profitabilitas suatu perusahaan mencerminkan tingkat efektifitas yang dicapai oleh suatu operasional perusahaan (Saleh, 2004). Profitabilitas menunjukkan keberhasilan perusahaan di dalammenghasilkan keuntungan. Dengan demikian, dapat dikatakan bahwa profit merupakan berita baik bagi perusahaan sehingga perusahaan tidak akan menunda penyampaian informasi yang berisi berita baik. Givoly dan Palmon (1982:489) 
ketepatan waktu dan keterlambatan pengumuman laba tahunan dipengaruhi oleh isi laporan keuangan. Jika pengumuman laba berisi berita baik, mungkin akan cenderung dilaporkan tepat waktu, sedangkan jika pengumuman laba berisi berita buruk maka pihak manajemen akan terlambat untuk menyampaikan laporan keuangan.

Leverage

Rasio leverage menunjukkan kemampuan perusahaan untuk membayar utang dengan ekuitas yang dimiliki. Weston dan Copeland (1995) menyatakan bahwa rasio leverage mengukur tingkat aktiva perusahaan yang telahdibiayai oleh penggunaan hutang. Leverage keuangan dapat diartika nsebagai penggunaan asset dan sumber dana (source of fund) oleh perusahaan yang memiliki biaya tetap dengan maksud meningkatkan keuntungan potensial pemegang saham. Suatu perusahaan yang memiliki leverage keuangan yang tinggi berarti memiliki banyak hutang pada pihak luar. Ini berarti perusahaan tersebut memiliki risikok euangan yang tinggi karena mengalami kesulitan keuangan (financial distress) akibat hutang yang tinggi. Penelitian Schwartz dan Soo (1996) menunjukkan bahwa perusahaan yang mengalami kesulitan keuangan cenderung tidak tepat waktu dalam menyampaikan laporan keuangannya disbanding perusahaan yang tidak mengalami kesulitan keuangan. Kesulitan keuangan juga merupakan berita buruk (bad news) sehingga perusahaan dengan kondisi seperti ini cenderung tidak tepat waktu dalam pelaporan keuangannya. Ukuran Perusahaan

Ukuran perusahaan merupakan pengelompokan perusahaan kedalam beberapa kelompok, diantaranya perusahaan besar, sedang dan kecil. Besar kecilnya ukuran perusahaan dapat didasarkan pada total nilai aktiva, total penjualan, kapitalisasi pasar, jumlah tenagakerja dan sebagainya. Semakin besar nilai item-item tersebut maka semakin besar pula ukuran perusahaan itu. Semakin besar aktiva maka semakinbanyak modal yang ditanam, semakin banyak penjualan maka semakin banyak perputaran uang dan semakin besar kapitalisasi pasar maka semakin besar pula ia dikenal dalam masyarakat. Perusahaan besar lebih konsisten untuk tepat waktu disbanding perusahaan kecil dalam menginformasikan laporan keuangannya, karena perusahaan besar banyak disorot oleh masyarakat. Perusahaan besar mempunyai pengetahuan lebih 
tentang peraturan yang ada, oleh karena itu perusahaan besar lebih mentaati peraturan mengenai ketepatan waktu dibanding perusahaankecil (Saleh, 2004).

Reputasi Kantor AkuntanPublik (KAP)

Perusahaan dalam menyampaikan suatu laporan atau informasi akan kinerja perusahaannya kepada publik agar akurat dan terpercaya diminta untuk menggunakan jasa KAP, sehingga dapat meningkatkan kredibilitas dari laporan itu, perusahaan menggunakan jasa KAP yang mempunyai reputasi atau nama baik. Hal ini biasanya ditunjukkan dengan KAP yang berafiliasi dengan KAP besar yang berlaku universal yang dikenal dengan Big Four Worldwide Accounting Firm (Big 4). Kantor akuntan besar disebutkan memiliki akuntan yang berprilaku lebih etika daripada akuntan di kantor akuntan kecil (Loeb, 1971). Dengan demikian, kantor akuntan besar lebih memiliki reputasi baik dalam opini publik. Sedangkan DeAngelo (1981) menyimpulkan bahwa KAP yang lebih besar dapat diartikan kualitas audit yang dihasilkan pun lebih baik dibandingkan kantor akuntan kecil. Maka dapat disimpulkan bahwa perusahaan yang memakai jasa KAP besa rcenderung tepat waktu dalam menyampaikan laporan keuangannya.

Komite Audit

Peranan komite audit adalah membantu dewan komisaris untuk memonitor proses pelaporan keuangan oleh manajemen untuk meningkatkan kredibilitas laporan keuangan (Bradbury et al., 2004). Tugas komite audit meliputi menelaah kebijakan akuntansi yang diterapkan oleh perusahaan, menilai pengendalian internal, menelaah system pelaporan eksternal dan kepatuhan terhadap peraturan. Di dalam pelaksanaan tugasnya komite menyediakan komunikasi formal antara dewan manajemen, auditor eksternal, dan auditor internal (Bradbury,et al. 2004). Adanya komunikasi formal antarakomite audit, auditor internal, dan auditor eksternal akanmenjamin proses audit internal dan eksternal dilakukan dengan baik. Proses audit internal dan eksternal yang baik akan meningkatkan akurasi laporan keuangan dan kemudian meningkatkan kepercayaan terhadap kualitas laporan keuangan (Anderson, et al. 2003). Dalam penelitian ini kualitas pelaporan keuangan yang dimaksud yaitu ketepatan waktu pelaporan keuangan. 


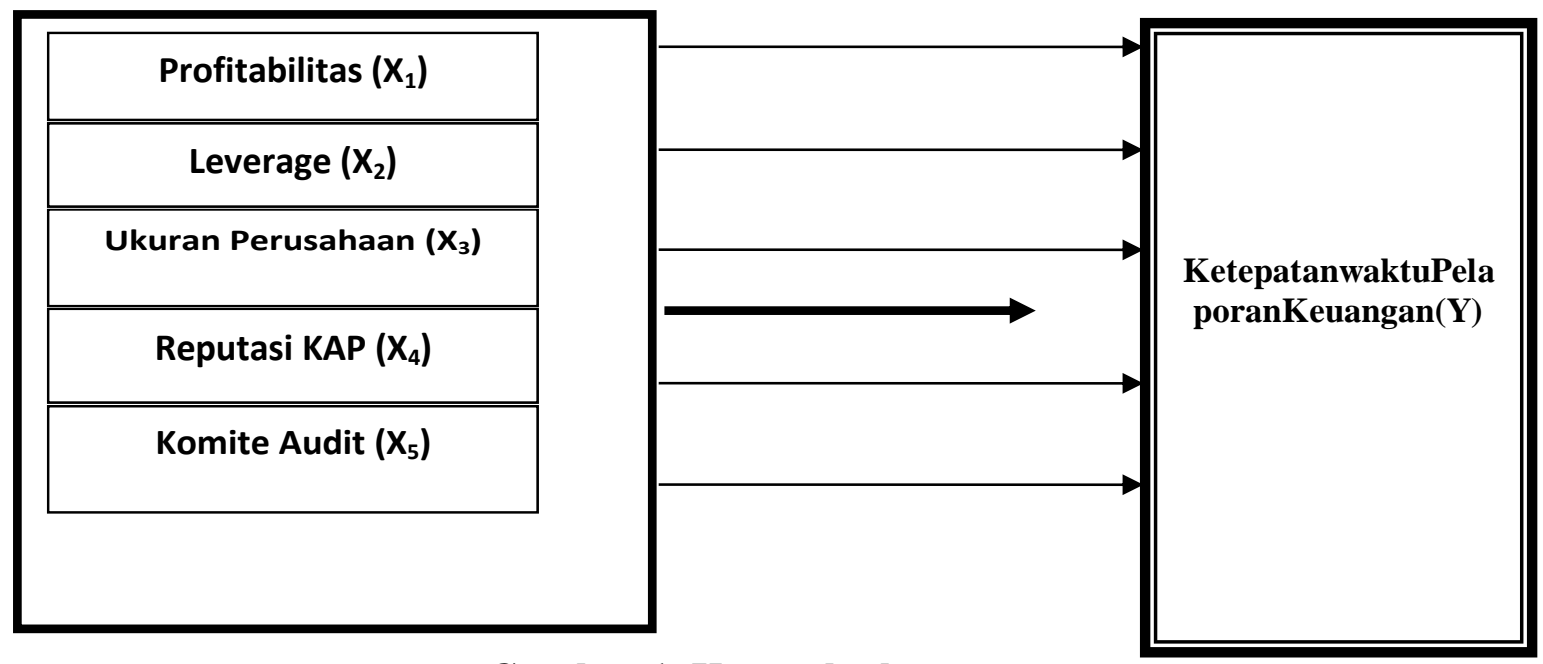

\section{Gambar 1. Kerangka konsep}

Berdasarkan kerangka konsep diatas, maka hipotesis dalam penelitian ini adalah sebagai beriklut :

H1 : Profitabilitas, leverage, ukuran perusahaan, reputasi kantor akuntan publik dan komite audit berpengaruh terhadap ketepatan waktu penyampaian laporan keuangan secara simultan pada perusahaan industri barang konsumsi yang terdaftar di Bursa Efek Indonesia periode 2012 -2016.

$\mathrm{H} 2$ : Profitabilitas berpengaruh positif terhadap ketepatan waktu penyampaian laporan keuangan pada perusahaan industri barang konsumsi yang terdaftar di Bursa Efek Indonesia periode 2012 -2016.

H3: Leverage berpengaruh negative terhadap ketepatan waktu penyampaian laporan keuangan pada perusahaan industri barang konsumsi yang terdaftar di Bursa Efek Indonesia periode 2012 -2016.

H4: Ukuran Perusahaan berpengaruh positif terhadap ketepatan waktu penyampaian laporan keuangan pada perusahaan industri barang konsumsi yang terdaftar di Bursa Efek Indonesia periode 2012 -2016.

H5 : Reputasi KAP berpengaruh positif terhadap ketepatan waktu penyampaian laporan keuangan pada perusahaan industri barang konsumsi yang terdaftar di Bursa Efek Indonesia periode 2012 -2016.

H6: Komite Audit berpengaruh positif terhadap ketepatan waktu penyampaian laporan keuangan pada perusahaan industri barang konsumsi yang terdaftar di Bursa Efek Indonesia periode $2012-2016$.

\section{Metode Penelitian}

Jenis penelitian ini adalah sebab akibat (causal research) yaitu penelitian yang bertujuan untuk menguji hipotesis dan merupakan penelitian yang menjelaskan fenomena dalam bentuk hubungan antarvariabel dan mengidentifikasi sebab akibat antara berbagaiv ariabel (Erlina, 2008). Populasi penelitian ini adalah perusahaan manufaktur khususnya yang termasuk dalam sector industry barang konsumsi yang terdaftar di Bursa Efek Indonesia dari tahun 2012 - 2016. Jumlah perusahaan sector 
barang konsumsi yang terdaftar di BEI sampai tahun 2016 adalahs ebanyak 37 perusahaan berdasarkan www.idx.co.id.

Kemudian dari populasi tersebut dijadikan data penelitian. Populasi penelitian ditentukan dengan metode sensus yaitu seluruh populasi yang memiliki kriteria dijadikan data dalam penelitianini. Periode pengamatan dilakukan dari tahun 2012 sampai tahun 2016. Total tahun pengamatan adalah lima tahun sehingga diperoleh 185 data yang akan diamati.

Analisis statistic inferensial dalam penelitian menggunakan analisis regresi logistik (logistic regression). Alasan menggunakan alat analisis regresi (logistic regression) adalah karena variabel dependen bersifat dummy (tepat waktu atau tidak tepat waktu menyampaikan laporan keuangan). Regresi logistic hamper sama dengan analisis deskriminanya itu digunakan untuk menguji apakah probabilitas terjadinya variabel terikat dapat diprediksi oleh variabel bebasnya (Ghozali,2011;333). Pengujian hipotesis logistik (logistic regression). Digunakan apabila variabel bebasnya merupakan kombinasi antara metrik dan non metrik (nominal). Regresi logistic adalah regresi yang di gunakan untuk menguji apakah probabilitas terjadinya variable dependen dapat diprediksi oleh varibel independen. Pada Teknik analisis regresi logistic tidak memerlukan lagi uji normalitas dan uji asumsi klasik pada varibel bebasnya (Ghozali,2011:333).

Analisis regresi logistik di gunakan untuk menguji apakah variabel-variabel profitabilitas, leverage, ukuran perusahaan, reputasi Kantor Akuntan Publik (KAP), komite audit dan kepemilikan manajerial berpengaruh terhadap ketepatan waktu pelaporan keuangan. Model regresi yang di kembangkan dalam penelitian ini sebagaiberikut:

$$
\mathrm{Y}=\beta 0+\beta 1 \mathrm{ROA}+\beta 2 \mathrm{DER}+\beta 3 \mathrm{MC}+\beta 4 \mathrm{KAP}+\beta 5 \mathrm{AC}+\varepsilon
$$

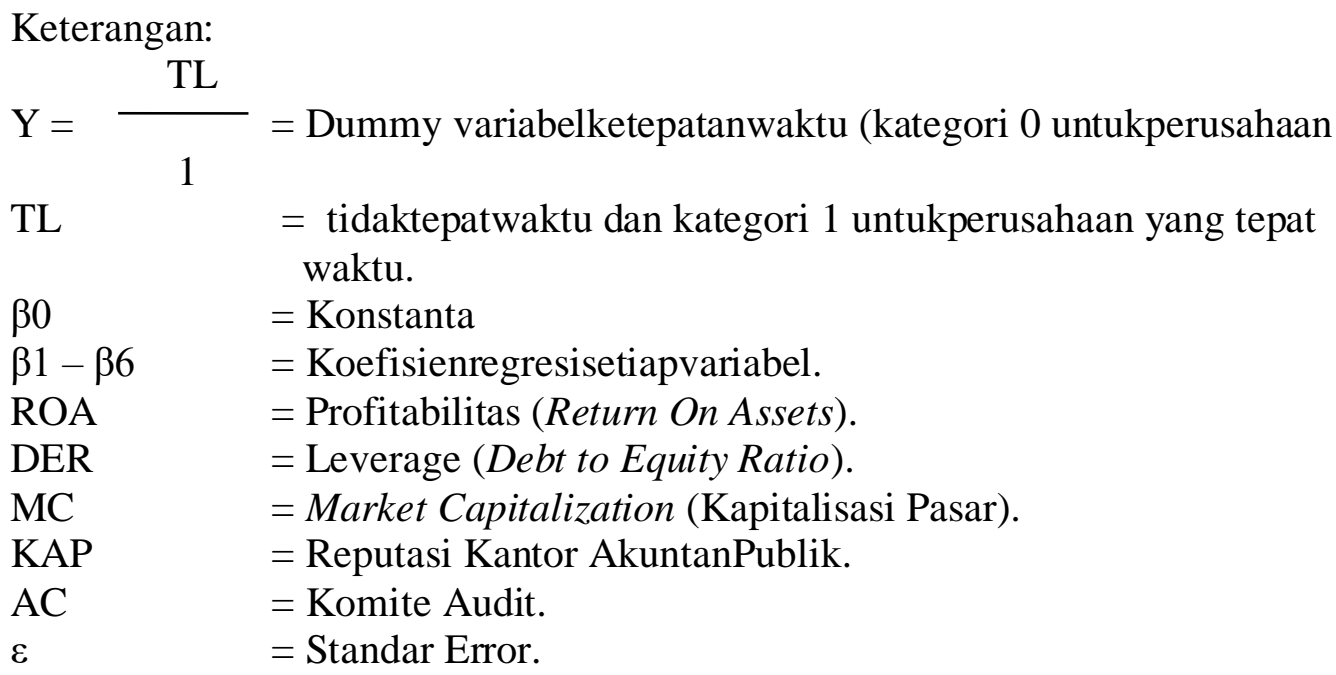

\section{Hasil Dan Pembahasan}

Statistik Deskriptif 
98 AT-TAWASSUTH: Jurnal Ekonomi Islam, Volume VI No. 1

Januari - Juni 2021: 90 - 106

Statistik deskriptif memberikan gambara nmengenai karakteristik variabel penelitian yang diamati.

Tabel 1. StatistikDeskriptif

\begin{tabular}{|l|l|l|l|l|l|l|}
\hline \multicolumn{7}{|c|}{ Descriptive Statistics } \\
\hline & $\mathrm{N}$ & Minimum & Maximum & Mean & Std. Deviation \\
\hline & Statistic & Statistic & Statistic & Statistic & Std. Error & Statistic \\
\hline ketepatanwaktu & 150 & 0 & 1 & .41 & .040 & .493 \\
\hline Profitabilitas & 150 & .10 & .66 & .1798 & .00771 & .09447 \\
\hline Leverage & 150 & .16 & 1.60 & .7105 & .02904 & .35572 \\
\hline UkuranPerusahaaan & 150 & 1.02 & 43.36 & 1.2798 & 30.163 & 36.69 \\
\hline Reputasi KAP & 150 & .00 & 1.00 & .5333 & .04087 & .50056 \\
\hline Komite Audit & 150 & 1.00 & 4.00 & 3.0333 & .03053 & .37393 \\
\hline Valid N (listwise) & 150 & & & & & \\
\hline & & & & & & \\
\hline
\end{tabular}

Sumber : Hasil Penelitian, 2016 (data diolah)

Hasil uji Hosmer and Lemeshow Goodness of Fit dapatdilihat pada table berikut:

Tabel 2. Hosmer and Lemeshow Test

\begin{tabular}{|l|l|l|l|}
\hline Step & Chi-square & df & Sig. \\
\hline 1 & 5.269 & 8 & .729 \\
\hline
\end{tabular}

Berdasarkan Tabel 2 diketahui nilai Sig. atauprobabilitas 0,729. Perhatikan bahwa karena nilai probabilitas, yakni 0,729 lebih besar dibandingkan tingkat signifikansi, yakni 0,05, maka secara keseluruhan model telah memenuhi persyaratan kelayakan model.

Hasil Omnibus Test of Model Coefficient dapatdilihat pada table sebagaiberikut:

Tabel 3. Omnibus Tests of Model Coefficients

\begin{tabular}{|ll|l|l|l|}
\hline & & Chi-square & df & Sig. \\
\hline Step 1 & Step & 13.075 & 6 & .042 \\
& Block & 13.075 & 6 & .042 \\
& Model & 13.075 & 6 & .042 \\
\hline
\end{tabular}

Berdasarkan tabel 3 menunjukkan bahwa secara simultan profitabilitas, leverage, ukuran perusahaan, reputasi KAP dan komite audit berpengaruh terhadap ketepatan waktu penyampaian laporan keuangan. Hal ini dilihat dari hasil chi-square 13,075 dengan nilai signifikansi $0,042<0,05$. 
Devi Ayu Putri S : Pengaruh Profitabilitas... $\mid 99$

Selain itu, menilai keseluruhan model dilakukan dengan cara memperhatikan angka pada -2 Log Likelihood (-2LL) Block Number $=0$ dan -2 Log Likelihood (-2LL) Block Number $=1$.

Tabel 4. Nilai -2 Log likelihood (-2 LL Awal)

\begin{tabular}{|c|c|c|c|}
\hline \multirow{2}{*}{\multicolumn{2}{|c|}{ Iteration }} & \multirow{2}{*}{$\begin{array}{l}-2 \text { Log } \\
\text { likelihood }\end{array}$} & Coefficients \\
\hline & & & Constant \\
\hline \multirow[t]{3}{*}{ Step 0} & 1 & 202.687 & -.373 \\
\hline & 2 & 202.687 & -.378 \\
\hline & 3 & 202.687 & -.378 \\
\hline
\end{tabular}

Tabel 5. Nilai -2 Log likelihood (-2 LL Akhir)

\begin{tabular}{|c|c|c|c|c|c|c|c|}
\hline \multirow[b]{2}{*}{ Iteration } & \multirow{2}{*}{$\begin{array}{l}-2 \text { Log } \\
\text { likelihood }\end{array}$} & \multicolumn{6}{|c|}{ Coefficients } \\
\hline & & Constant & $\mathrm{X} 1$ & $\mathrm{X} 2$ & $\mathrm{X} 3$ & $\mathrm{X} 4$ & X5 \\
\hline \multirow[t]{5}{*}{ Step 1} & 190.599 & -3.544 & .040 & .000 & .000 & .216 & .790 \\
\hline & 189.837 & -4.172 & .045 & . 000 & -.001 & .233 & .963 \\
\hline & 189.622 & -4.153 & .047 & .000 & -.002 & .235 & .957 \\
\hline & 189.612 & -4.143 & .047 & .000 & -.002 & .236 & .954 \\
\hline & 189.612 & -4.143 & .047 & .000 & -.002 & .236 & .954 \\
\hline
\end{tabular}

Tabel 6. Menguji Model Fit

\begin{tabular}{|l|l|l|}
\hline $\begin{array}{l}\text { Nilai - } \\
\text { 2Loglikelihood }\end{array}$ & \multicolumn{1}{|c|}{ Keterangan } \\
\cline { 1 - 2 } Awal & Akhir & \\
\hline 202,687 & 189,612 & $\begin{array}{l}\text { Adanya penurunan nilaiantara -2LLawal (initial-2LL } \\
\text { function) dengan nilai-2LL pada Langkah berikutnya (-2LL } \\
\text { akhir) menunjukkan bahwa model yang dihipotesiskan fit } \\
\text { dengan data (Ghozali, 2013). Penurunan nilai-2 log } \\
\text { likelihood menunjukkan bahwa model penelitian ini } \\
\text { dinyatakan fit, artinya penambahan-penambahan variabel } \\
\text { bebas yaitu profitabilitas, leverage, ukuran perusahaan, } \\
\text { reputasi KAP dan komite audit kedalam model logisitk akan } \\
\text { memperbaiki model fit dalam penelitian ini (model fit atau } \\
\text { layak). }\end{array}$ \\
\hline
\end{tabular}

Berdasarkan Tabel 6 penurunan nilai -2 log likelihood menunjukkan bahwa model penelitian ini dinyatakan fit, artinya penambahan-penambahan variabel bebas yaitu profitabilitas, leverage, ukuran perusahaan, reputasi KAP dan komite audit 
kedalam model logisitk akan memperbaiki model fit dalam penelitian ini (model fit atau layak).

Hasil model summary dapat dilihat pada table sebagai berikut :

Tabel 7. Model Summary

\begin{tabular}{|l|l|l|l|}
\hline Step & $\begin{array}{l}-2 \text { Log } \\
\text { likelihood }\end{array}$ & $\begin{array}{l}\text { Cox \& Snell R } \\
\text { Square }\end{array}$ & $\begin{array}{l}\text { Nagelkerke R } \\
\text { Square }\end{array}$ \\
\hline 1 & $189.612^{\mathrm{a}}$ & .083 & .113 \\
\hline
\end{tabular}

Berdasarkan Tabel 7 nilai statistic Nagelkerke R Square 0,113. Nilai tersebu tdiinterpretasikan sebagai kemampua nprofitabilitas, leverage, ukuran perusahaan, reputasi KAP dan komite audit dalam mempengaruhi ketepatan waktu pelaporan keuangan sebesar $11,3 \%$, sisanya $88,7 \%$ dijelaskan oleh variabel-variabel atau faktorfaktor lain.

\section{Kesimpulan}

1. Berdasarkan hasil pengujian dapat disimpulkan bahwa profitabilitas, leverage, ukura nperusahaan, reputasi Kantor Akuntan Publik (KAP) dan komite audit secara simultan berpengaruh signifikan terhadap ketepatan waktu pelaporan keuangan pada perusahaan manufaktur sektor industri barang konsumi yang terdaftar di BEI tahun 2012-2016.

2. Berdasarkan hasil pengujian dapat disimpulkan bahwa profitabilitas berpengaruh signifikan terhadap ketepatan waktu pelaporan keuangan pada perusahaan manufaktur sektor industri barang konsumi yang terdaftar di BEI tahun 2012-2016.

3. Berdasarkan hasil pengujian dapat disimpulkan bahwa leverage tidak berpengaruh signifikan terhadap ketepatan waktu pelaporan keuangan pada perusahaan manufaktur sektor industri barang konsumi yang terdaftar di BEI tahun 2012-2016.

4. Berdasarkan hasil pengujian dapat disimpulkan bahwa ukuran perusahaan tidak berpengaruh signifikan terhadap ketepatan waktu pelaporan keuangan pada perusahaan manufaktur sektor industri barang konsumi yang terdaftar di BEI tahun 2012-2016. 
Devi Ayu Putri S : Pengaruh Profitabilitas... $\mid 101$

5. Berdasarkan hasil pengujian dapat disimpulkan bahwa reputasi Kantor Akuntan Publik (KAP) tidak berpengaruh signifikan terhadap ketepatan waktu pelaporan keuangan pada perusahaan manufaktur sektor industri barang konsumi yang terdaftar di BEI tahun 2012-2016.

6. Berdasarkan hasil pengujian dapat disimpulkan bahwa komite audit berpengaruh signifikan terhadap ketepatan waktu pelaporan keuangan pada perusahaan manufaktur sektor industri barang konsumi yang terdaftar di BEI tahun 2012-2016.

\section{Daftar Pustaka}

Abbott, L. J., Parker, S., Peters, G.F. and Raghunandan, K. (2003), “The association between audit committee characteristics and audit fees", Auditing: A Journal of Practice and Theory. Vol.22 No.2, pp.17-32.

Anderson, et al. (2003). Board of Directors, Audit Committees, and Information ContentofEarnings. Working Papers, September.

Ang, Robert. 2007. BukuPintar Pasar Modal Indonesia (The Intelligent Guide To Indonesian Capital Market). EdisiPertama. Mediasoft Indonesia. Jakarta.

Annisa, Nur, 2004, “Ketepatan Waktu Penyampaian Laporan Keuangan: Kajian Atas Kinerja Manajemen, Kualitas Auditor, dan Opini Audit”. Fakultas Ekonomi Universitas Katolik Indonesia Atma Jaya. JurnalAkuntansi, Auditing dan Keuangan. Vol. 1 No. 2 Hal 42-53. September, 2004.

Antle, R and B. Nalebuff. 1991. Conservatism and Auditor-Client Negotiations. Journal of Accounting Research, Vol. 29, pp 31-54.

Astuti, Christina Dwi. 2007. "Faktor-faktor yang berpengaruhterhadapketepatan waktu pelaporan keuangan”. JurnalInformasi, Perpajakan, Akuntansi dan Keuangan Publik Volume 2, No. 1, Januari, Hal. 27-42.

Bandi, dan Hananto, Santoso Tri. 2000. "Ketepatan waktu atas laporan keuangan perusahaan Indonesia”. Simposium Nasional Akuntansi III Ikatan Akuntan Indonesia.Hal : 66-77

Baridwan, Zaki. 1997. Intermediate Accounting. Edisi 7. Yogyakarta: BPFE.

Beasley, M.S., and Salterio S.E. 2001. Relation Between Boards Characteristics and Voluntary Improvements in Audit Committee Composition an Experience. AccountingResearch, Vol.18 No.4, pp.539-70. 
Bradbury, et al. (2004). Board Characteristics, Audit Committee Characteristics and Abnormal Accruals. Working Paper, Unitec New Zealand danNational University of Singapore.

Carcello, J.V. and Neal, T.L.2000."Audit Committee Composition and Auditor Reporting." The Accounting Review.Volume 75 No. 4. Pp 453-467.

Carslaw, C.A.P.N., and Kaplan, S.E.,(1991). "An Examination of Audit Delay: Further Evidence from New Zealand". Accounting and Business Research,Vol. 22. No. 85. pp. 21-32.

Chambers, A. E and S. H . Penman. 1984. "Timeliness of Reporting and the Stock Price Reaction to Earnings Announcements". Journal of Accounting Research. Hal 204-220.

Chariri, Anis dan Imam Ghozali. 2001. TeoriAkuntansi. Semarang: Badan Penerbit Universitas Diponegoro.

DeAngelo, LE (1981). "Auditor Size and Auditor Quality". Journal of Accounting and Economics, Dec, Vol.3, No.3:183-199.

DeFond, M.L. and J. Jiambalvo. 1994. "Debt Covenant Effects and the Manipulation of Accruals". Journal of Accounting und Economics, Vol. 17, pp 145-176.

Dye. (1993). “Auditing Standards, Legal Liability”, and Auditor Wealth. Journal of Political Economics, Vol.101, pp.887-914.

Dyer, J. C. I. V., and A. J. McHugh. 1975. The Timeliness of The Australian Annual Report.

Emirzon, Joni. 2007. "Prinsip-prinsip Good Corporate Governance Paradigma Baru dalam Praktik Bisnis Indonesia”, Cetakan 1, Yogyakarta: Genta Press.

Givoly, D., and Palmon D. 1982. "Timeliness of Annual Earning Announcements: Some Empirical Evidence”. The Accounting Review. Vol. LVII, No.3.

Gunarsih, \& Bambang. (2008). Struktur Corporate Governance dan Ketepatan Waktu PenyampaianLaporanKeuangan : Studi Pada Perusahaan Jasa di BEI. JurnalKeuangan dan Perbankan , 204-216.

Hanafi, Mamduh H dan Abdul Halim. 2003. AnalisisLaporanKeuangan, edisi pertama. Yogyakarta: Penerbit UPP STIM YKPN. 
Hilmi, Utari dan Syaiful Ali. 2008. AnalisisFaktor-Faktor Yang Mempengaruhi Ketepatan Waktu PenyampaianLaporanKeuangan(StudiEmpiris pada Perusahaan-perusahaan yang Terdaftar di BEJ). Proseding Simposium Nasional Akuntansi XI IkatanAkuntan Indonesia.

Ifada, LulukMuhimatul. 2009. Faktor-Faktor Yang Mempengaruhi Ketepatwaktuan Pelaporan Keuangan (Studi Kasus Perusahaan Manufaktur di Bursa Efek Jakarta), Jurnal Akuntansi Indonesia. Vol. 5. Hal. 43-56.

IkatanAkuntan Indonesia (IAI). 2002. StandarAkuntansiKeuangan.Jakarta: SalembaEmpat.

IkatanAkuntan Indonesia (IAI). 2012. StandarAkuntansiKeuangan. PSAK. CetakanKeempat, Buku Satu, PenerbitSalembaEmpat, Jakarta.

Jensen, M. C and Meckling, W.H. 1976. Theory of Firm : Managerial Behavior Agency Costs and Ownership Structure. Journal of Financial Economics, pp 305-360.

Downes, John and Jordan Elliot Goodman. 1999. KamusIstilahAkuntansi, Jakarta, PenerbitElex Media Komputindo. Journal of Accounting Research. Autumn. Vol. 13. No.2. Hal: 204-219.

Kadir, Abdul. 2011. Faktor-Faktor Yang BerpengaruhTerhadapKetepatan Waktu Pelaporan Keuangan Studi Empiris Pada Perusahaan Manufaktur di Bursa Efek Jakarta. Jurnal ManajemenAkuntansi, Vol.1 No.1, Sekolah Tinggi IlmuEkonomi Indonesia.

Klien. (2001). Audit Committee, Board of Director Characteristic and Earnings Management. Journal Accounting and Economics , Vol. 33, 375-400.

KNKCG. (2002). Pedoman Good Corporate Governance. Jakarta.

Loeb, S.E. 1971. "A Survey of Ethical Behavior in the Accounting Profession”. Journal of Accounting Research: 287-306.

McGee, Robert W. 2007. "Corporate Governance and The Timeliness of Corporate Financial Reporting : A case Study of The Russian Energy Sector". Andreas of school and Bussines Working Paper. Barry University USA.

Midiastuty, P., and Machfoedz. (2003). Analisis Hubungan Mekanisme Corporate Governance dan Indikasi Manajemen Laba. Makalah SNA VI, 176199.

Mullen, M. and Raghunandan (1996). Audit Committe Performance : An Investigation of the Consequences Associated with Audit Committees. Auditing: A Journal of Practice and Theory, Vol.15, No.1,pp.88-103. 
104 AT-TAWASSUTH: Jurnal Ekonomi Islam, Volume VI No. 1 Januari - Juni 2021: 90 - 106

Munawir. 1995. AnalisisLaporanKeuangan. EdisiPertama. Liberty, Yogyakarta.

Naim. 1998. Timeliness of Annual Financial Statement Submission : A preliminary Empirical Evidence From Indonesia. Makalah. Universitas Gajah Mada.

Nurfauziah, Farah Latifah. 2016. "PengaruhProfitabilitas, Ukuran Perusahaan, Leverage, dan Reputasi Kantor Akuntan Publik Terhadap Ketepatan Waktu Pelaporan Keuangan Audited". JurnalEkonomi dan Bisnis.Vol.1 No.1. Juli 2016. Fakultas Ekonomi Universitas Islam Nusantara

Nurmiati. 2016. Faktor-Faktor Yang MempengaruhiKetepatanwaktuPelaporan Keuangan , JurnalEkonomi dan Manajemen. Vol. 13 No. 2 Hal. 166182. Fakultas Ekonomi dan Bisnis Universitas Mulawarman.

Owusu, Stephen and Ansah, 2000. "Timeliness of Corporate Financial Reporting in Emerging Capital Market: Empirical Evidence From The Zimbabwe Stock Exhange". Journal Accounting and Business Research, Volume 30. No.3. pp.241-254.

Respati, Novita WeningTyas. 2004. Faktor-Faktor yang Berpengaruhterhadap 104 Ketepatan Waktu Pelaporan Keuangan: StudiEmpiris di Bursa Efek Jakarta. JurnalMaksi. Vol.4. Januari 2004.hal 67-81.

Riyanto, Bambang. 2001. Dasar-Dasar Pembelanjaan Perusahaan, EdisiKeempat, CetakanKetujuh, BPFE Yogyakarta, Yogyakarta.

Ross, et al. (1999). Corporate Finance, 5th edition. Singapore: Irwin McGraw Hill.

Saleh, Ranhmat. 2004. Studi Empiris Ketepatan waktu Pelaporan Keuangan Perusahaan Manufaktur di Bursa Efek Jakarta, Simposium Nasional Akuntansi VII Denpasar Bali,2-3 Desember 2004.

Sanjaya, I Made Dwi Marta dan Ni GustiWirawati. 2016. “AnalisisFaktor-Faktor yang Mempengaruhi Ketepatan Waktu Pelaporan Keuangan Pada Perusahaan Manufaktur yang Terdaftar di BEI'. E-JurnalAkuntansi Universitas Udayana Vo.15.1. April: 17-25 ISSN: 2302-8556.

Schwartz, K. and B. Soo, 1996. Evidence of Regulatory Non-complience with SEC Disclosure Rules on Auditor Changes. The Accounting Review 4 (October): 555-572.

Srimindarti, Ceacilia. 2008. Ketepatan Waktu PelaporanKeuangan, Fokus Ekonomi, Vol. 7 No. 1, April 2008, hal 14-21. Semarang: Fakultas Ekonomi Universitas Stikubank. 
Devi Ayu Putri S : Pengaruh Profitabilitas... 105

Sri Purwati, Atiek. 2006. PengaruhKarakteristikKomite Audit Terhadap Ketepatan Waktu PelaporanKeuangan Pada Perusahaan Publik Yang Tercatat Di BEI. Tesis: Universitas Diponegoro.

Suharli, Michell dan Sofyan S. Harahap. 2008. Timeliness LaporanKeuangan Di

Indonesi (StudiEmpirisTerhadapEmiten Bursa Efek Jakarta). Media

RisetAkuntansi, Auditing ～dan Informasi, Vol.8 No.2. Agustus 2008, 97-

116.Jakarta : Universitas KatolikIndonesia Atmajaya dan Universitas

Trisakti.

Suharli dan Rachpriliani. 2006, StudiEmpirisFaktor-Faktor Yang Berpegaruh erhadap Ketepatan Waktu PelaporanKeuangan, JurnalBisnis dan Akuntansi, Vol 8 No. 1, April 2006.

Suwito dan Herawaty. 2005. "AnalisisPengaruh Karakteristik Perusahaan Terhadap Tindakan Perataan Laba yang dilakukan oleh Perusahaan yang Terdaftar di Bursa Efek Jakarta”. SNA VIII Solo. September.

Soekadi, Eddy, P, Mekanisme Leasing, Ghalia Indonesia, Jakarta, 1990.

Syafruddin, 2004. "Pengaruh Ketidaktepatan waktu Penyampaian Laporan Keuangan pada Earning Response Coeffcient :Studi Pada Bursa Efek Jakarta “,Simposium Nasional AkuntansiVII.Hal 754-776.

Tuanakotta, Theodorus, M. 2007. Akuntansi Forensik\& Audit Investigatif, Jakarta:Lembaga Penerbit Fakultas Ekonomi Universitas Indonesia.

Turel, A., \& Dali, M. A. (2010). Timeliness of Financial Reporting in Emerging Capital Markets: Evidence from Turkey. Journal of the School of Business Administration, Vol. 39(2), Hal. 227-240.

Toding, Merlina dan Made GedeWirakusuma. 2013. Faktor-Faktor Yang Mempengaruhi Ketepatwaktuan Penyampaian Laporan Keuangan. EJurnalAkuntansi Universitas Udayana Vol. 3 No. 2. Hal. 318-333.

Ukago, Kristianus. 2004. "Faktor-Faktor yang BerpengaruhTerhadapKetepatan Waktu PelaporanKeuangan : Bukti EmpirisEmiten di Bursa Efek Jakarta". Tesis Program PascaSarjana Magister SainsAkuntansi. Universitas Diponegoro Semarang.

Weston, J. Fred., and Thomas E. Copeland. 1995. Managerial Finance 9th ed., The Dryden Press, 1992. Terjemahan A. JakaWasana dan Kibrandoko, Manajemen Keuangan, Jakarta: BinarupaAksara.

Wirakusuma, Made Gede. 2004. Faktor-Faktor yang Mempengaruhi Rentang Waktu Peyajian Laporan Keuangan ke Publik. Makalah Disampaikan dalamSimposium Nasional Akuntansi VII IkatanAkuntan Indonesia., Denpasar. 
106 AT-TAWASSUTH: Jurnal Ekonomi Islam, Volume VI No. 1

Januari - Juni 2021: 90 - 106

Yusralaini, Restu Agusti dan Livia Dara Raesya. 2010. “Analisis Faktor-faktor yang Mempengaruhi Ketepatan Waktu Penyampaian Laporan Keuangan Publik pada Perusahaan yang Terdaftar di BEI (2005-2007)". Jurnal Ekonomi. Volume 13 Nomor 2 hal 6-16, Universitas Riau, Pekanbaru. 